\title{
Modeling the impact of agricultural land use and management on US carbon budgets
}

\author{
B. A. Drewniak ${ }^{1}$, U. Mishra ${ }^{1}$, J. Song ${ }^{2}$, J. Prell ${ }^{1}$, and V. R. Kotamarthi ${ }^{1}$ \\ ${ }^{1}$ Environmental Science Division, Argonne National Laboratory, 9700 S. Cass Ave, Argonne, IL 60439, USA \\ ${ }^{2}$ Northern Illinois University, Department of Geography, Davis Hall, Room 118, DeKalb, IL 60115, USA \\ Correspondence to: B. Drewniak (bbye@anl.gov)
}

Received: 20 August 2014 - Published in Biogeosciences Discuss.: 22 September 2014

Revised: 5 March 2015 - Accepted: 10 March 2015 - Published: 9 April 2015

\begin{abstract}
Cultivation of the terrestrial land surface can create either a source or sink of atmospheric $\mathrm{CO}_{2}$, depending on land management practices. The Community Land Model (CLM) provides a useful tool for exploring how land use and management impact the soil carbon pool at regional to global scales. CLM was recently updated to include representation of managed lands growing maize, soybean, and spring wheat. In this study, CLM-Crop is used to investigate the impacts of various management practices, including fertilizer use and differential rates of crop residue removal, on the soil organic carbon (SOC) storage of croplands in the continental United States over approximately a 170-year period. Results indicate that total US SOC stocks have already lost over $8 \mathrm{Pg} \mathrm{C}$ $(10 \%)$ due to land cultivation practices (e.g., fertilizer application, cultivar choice, and residue removal), compared to a land surface composed of native vegetation (i.e., grasslands). After long periods of cultivation, individual subgrids (the equivalent of a field plot) growing maize and soybean lost up to $65 \%$ of the carbon stored compared to a grassland site. Crop residue management showed the greatest effect on soil carbon storage, with low and medium residue returns resulting in additional losses of 5 and $3.5 \%$, respectively, in US carbon storage, while plots with high residue returns stored $2 \%$ more carbon. Nitrogenous fertilizer can alter the amount of soil carbon stocks significantly. Under current levels of crop residue return, not applying fertilizer resulted in a $5 \%$ loss of soil carbon. Our simulations indicate that disturbance through cultivation will always result in a loss of soil carbon, and management practices will have a large influence on the magnitude of SOC loss.
\end{abstract}

\section{Introduction}

Bioenergy crops are promoted as a renewable energy source capable of improving energy security and mitigating greenhouse gas (GHG) emissions from fossil fuels. These crops are considered environmentally friendly and economically competitive because $\mathrm{CO}_{2}$ emitted by biofuel combustion is partially balanced by atmospheric uptake through photosynthesis (Hughes et al., 2010). The Renewable Fuel Standard of the US Energy Independence and Security Act (EISA 2007) sets a national target of producing 136 billion liters of renewable fuels by 2022. Of this, at least 61 billion liters is expected to come from cellulosic ethanol (US Environmental Protection Agency, 2010). Though maize grain and sugarcane are currently the major global sources for bioethanol production, maize production in the United States is not sufficient to meet the renewable fuel targets. Furthermore, recent studies suggest that production of ethanol from maize grain might in fact increase GHG emissions because of changes in land use (Searchinger et al., 2008; Kim et al., 2009; Melillo et al., 2009). For these reasons, cellulosic biofuels produced from cellulose and hemicellulose plant biomass are considered a viable alternative to conventional crop-based biofuels.

Cellulosic biofuels can be made from perennial feedstocks or from residues of annual cropping and forestry activities, thereby reducing or eliminating the need for additional agricultural land. The use of crop residues for bioethanol production shows promise for fulfilling US renewable fuel goals, but more research is needed on the effects on soil organic carbon (SOC) of crop residue removal from croplands (Mishra et al., 2013) and net GHG balance (McKone et al., 2011). Furthermore, crop residues play a crucial role in sustainability and 
resilience of agroecosystems (Karlen et al., 2009). Therefore, to understand the environmental consequences of using crop residues for bioenergy production on large spatial scales, it is essential to know the impacts on the SOC pool of differential rates of crop residue removal and nitrogenous fertilizer applications.

Crop residue is responsible for maintaining soil moisture, returning carbon and other nutrients to soil, and erosion mitigation; in general, it provides a sustainable environment for cultivation activities (Lal, 2009). Without residue cover, wind and water erosion will increase (Van Pelt et al., 2013). Longterm residue harvest results in loss of yields and productivity by decreasing the nutrient content of soils (Blanco-Canqui and Lal, 2009a). These arguments demonstrate that using crop residues as a bioenergy fuel resource could have detrimental impacts on agroecosystems (Blanco-Canqui and Lal, 2009a).

Globally, soils store more carbon than the atmosphere and biosphere combined, acting both as a source and sink of atmospheric $\mathrm{CO}_{2}$ (IPCC, 2013). However, cultivation loss of SOC ranges from 50 to $70 \%$ (Lal and Bruce, 1999). Over the US Midwest, land conversion led to a $25-50 \%$ reduction of soil carbon (Houghton et al., 1999; Lal, 2002). The result is large carbon payback times, ranging from a few years to several centuries (Fargione et al., 2008; Gibbs et al., 2008; Searchinger et al., 2008). On the other hand, conversion from cultivation to native grasslands, such as through enrollment in the Conservation Reserve Program, resulted in increased soil carbon (Anderson-Teixeira et al., 2009; Pineiro et al., 2009). Therefore, it is critical to evaluate the impact of agricultural land use and management on regional carbon budgets.

The influence of agriculture on the carbon cycle is complex; carbon capture and storage in croplands are dependent on management practices, including tillage, fertilizer applications, residue management, and crop sequence (West and Post, 2002; Hooker et al., 2005; Dou and Hons, 2006; Huggins et al., 2007; Khan et al., 2007; Kim et al., 2009). SOC stocks and fluxes at a particular location are soil and site specific and reflect the long-term balance between organic matter inputs from vegetation and losses due to decomposition, erosion, and leaching. Some studies have attempted to quantify carbon sequestration from mitigation strategies such as no-till or conservation tillage practices, residue management, use of cover crops, and restoration and reserve actions (Conant et al., 2001; West and Post, 2002). These studies have shown that as farming techniques are improved to maximize yield and minimize disturbance, SOC can be maintained and perhaps even increased over time.

However, the effect of altered management on agricultural soil's ability to store or emit carbon is unresolved, largely as a result of conflicting evidence. For example, some studies on the effects of nitrogen fertilizer indicated a decrease in SOC caused by increased decomposition (Khan et al., 2007; Russell et al., 2009), while others reported an increase in
SOC from increased biomass returned to the soil after harvest (Jung and Lal, 2011; Halvorson et al., 1999; Wilts et al., 2004). SOC increases when crop residue is returned to the land (Buyanovsky and Wagner, 1998; Wilhelm et al, 2004; van Groenigen et al., 2011), but residue can also increase decomposition in warm, moist areas (Johnson et al., 2005). Perhaps the disagreement is the result of the large variability and uncertainty of field measurements, which make developing conclusions difficult (Karlen et al., 2011). For example, Smith et al. (2012) found no differences between the residuereturned and residue-harvested treatments, and in some cases the residue-harvested sites had increased SOC. Thorburn et al. (2012) also found no consensus regarding residue harvest and SOC response. Nonetheless, most studies found a loss of SOC with residue harvesting. Although the variability of SOC measurements can be attributed to any number of effects - including topography (Senthilkumar et al., 2009b), baseline SOC (Senthilkumar et al., 2009a), aggregate protection (Ananyeva et al., 2013), and even depth (Kravchenko and Robertson, 2011; Syswerda et al., 2011) - it is generally agreed that if crop residue is used as feedstock for biofuels, additional carbon losses can occur (Karlen et al., 2011).

SOC losses can be mitigated through recommended management practices, but studies disagree on the limits of harvestable crop residue to maintain SOC levels in soils. Estimates of harvestable non-grain biomass range from $13 \%$ (Tan et al., 2012) to $50 \%$ (Blanco-Canqui and Lal, 2009a), with an average of about $25 \%$, although that might require the stabilization of SOC (Tan et al., 2012). These estimates consider erosion, soil productivity, maintaining SOC, surface crusting, porosity, aggregate breakdown, compaction, and soil temperature, but the wide range in estimated biomass available for harvest leaves questions regarding the sustainability of cellulosic ethanol. However, because the rate of SOC loss tends to increase with increased biomass harvest (Lemke et al., 2010), harvesting small amounts of residue for biofuel might be feasible.

Modeling studies can supplement observational data and explore possible differences in SOC by investigating idealized cases. A benefit is that the wide study area can be extended to regional or global scales without resorting to geospatial methods of interpolating sparse data. In this study, we evaluated the influence of cultivation on SOC by using the agriculture version of the Community Land Model (CLM), CLM-Crop (Drewniak et al., 2013). Our analysis includes impacts of changes in land use and also in management practices, such as crop residue harvesting and fertilizer application. A description of the model and the simulations performed is presented in Sect. 2, followed by results and a discussion in Sects. 3 and 4, respectively. 


\section{Methods}

\subsection{CLM-Crop model description}

CLM-Crop, the agriculture version of CLM, includes representations of maize, spring wheat, and soybean crop types with fully coupled carbon-nitrogen cycling (Drewniak et al., 2013). The variation of carbon and nitrogen allocation to plant components with the growth phase of crop development is based on the dynamic vegetation model Agro-IBIS (Kucharik and Brye, 2003). The growth phases are defined as planting, emergence, grain fill, and harvest. Plant date and growth period are determined from the Crop Calendar Dataset (Sacks et al., 2010), and each phase is reached according to a phenological heat unit (PHU) method (see Drewniak et al., 2013).

Several processes governing nitrogen cycling are included in CLM-Crop to represent nitrogen retranslocation, fertilization, and nitrogen fixation in soybeans. Nitrogen retranslocation occurs during the grain fill growth phase, when nitrogen in the leaves and stem are mobilized to meet organ demands. Fertilizer is applied during the emergence phase for 20 days at constant rates of $150 \mathrm{~kg} \mathrm{ha}^{-1}$ for maize, $80 \mathrm{~kg} \mathrm{ha}^{-1}$ for spring wheat, and $25 \mathrm{~kg} \mathrm{ha}^{-1}$ for soybean. The 20 -day fertilization period is designed to optimize nitrogen usage and reduce loss of excess nitrogen through denitrification. Soybean nitrogen fixation allows soybean crops to behave as legumes fixing additional nitrogen through roots - a treatment similar to that of the Soil and Water Assessment Tool (SWAT) (Neitsch et al., 2005).

Harvest occurs as soon as maturity is reached. Grain is removed from the system to represent the consumption of that plant component. The remaining stems and leaves are considered residue and are split into litter and product pools. Litter is returned to the soil through the decomposition process, while product is removed with the grain for uses such as biofuels, animal bedding, etc. The amount of residue returned as litter can be varied for different scenarios. High returns represent sustainable agriculture practices to maintain soil fertility, and low returns are indicative of high cellulosic biofuel usage.

\subsection{Input data}

CLM-Crop requires two types of input: climate data and surface data. The climate data from the National Center for Environmental Protection reanalysis for 1948-2004 (Kalnay et al., 1996) include temperature, wind speed, humidity, precipitation, solar radiation, and surface pressure at $3 \mathrm{~h}$ intervals. Because the spin-up of the model requires over 600 years of simulation, we cycled through the reanalysis data to reach a steady state (Thornton and Rosenbloom, 2005).

Surface data sets assign the proportion of each land type and plant functional type in a grid cell; crops are grown separately from natural vegetation to eliminate competition for resources. Natural vegetation prescribed from Bonan et al. (2002) includes a generic crop area. Crop distribution for 1992 from Leff et al. (2004) is used to construct maize, wheat, and soybean coverage from the total generic crop area. Because the wheat coverage includes both spring and winter wheat, we model winter wheat as spring wheat in CLM-Crop. Some crop areas might be overestimated as double cropping in the data set might result in a crop area being counted twice.

In addition to land use, the surface data include the planting dates and growth period of each crop type from the Crop Calendar Dataset (Sacks et al., 2010). Planting date is the average day of the year when planting occurs, aggregated from $0.5^{\circ}$ resolution to $2.8^{\circ}$ for CLM-Crop. In regions where data are not available, Sacks et al. (2010) used nearest-neighbor extrapolation to infer planting date. Growth period is calculated in Sacks et al. (2010) as the average number of PHUs between the average planting date and the average harvest date for the 30-year Climatic Research Unit data set (New et al., 1999).

\subsection{Simulations}

CLM-Crop was run at a resolution of $2.8^{\circ} \times 2.8^{\circ}$ by using the spin-up procedure in Thornton and Rosenbloom (2005). During spin-up, only natural vegetation was active, and croplands were simulated as grass until a steady SOC state was reached. At the end of the spin-up, the land use was converted to include agriculture, representative of the early 1990s land use maps from Leff et al. (2004). CLM does not have a dynamic vegetation capability when crops are active, so land use/land cover is held constant for the remaining simulations. Several case studies were designed and run to evaluate the influence of management practices on SOC (Table 1). Each case study was run for a total of 171 years (three complete cycles of the 1948-2004 data) at an hourly time step to represent the most intense cultivation period in North America (Ramankutty and Foley, 1999). However, we consider only the last 57 years of simulation for analysis with averaged data. The control simulation, representing current fertilizer and management practices over North America, is compared to an extension of the spin-up, with crops represented as grass. Additional experiments compared the impact on soil carbon from four agricultural practices (high, medium, and low residue levels and zero fertilizer) with our control simulation.

To investigate the effects of land use changes on SOC, different residue management practices, and varied fertilizer application, the results from six scenarios were analyzed (Table 1). First, conventional crop management (control run, $70 \%$ residue) is compared with crops simulated as grass (grass run). Second, effects of high (90\%), medium (30$40 \%$ ), and low (10\%) residue are compared with values for the control run. Third, the effect of no fertilizer application 
Table 1. CLM-Crop simulations performed.

\begin{tabular}{llll}
\hline Run name & Land use & Fertilizer & Residue \\
\hline Control & Leff et al. (2004) & Yes & $70 \%-$ all crops \\
High residue & Leff et al. (2004) & Yes & $90 \%-$ all crops \\
Medium residue & Leff et al. (2004) & Yes & $30 \%-$ maize \\
& & & $30 \%-$ wheat \\
& & & $40 \%-$ soybean \\
Low residue & Leff et al. (2004) & Yes & $10 \%-$ all crops \\
No fertilizer & Leff et al. (2004) & No & $70 \%-$ all crops \\
Grass & Bonan et al. (2002) & Not applicable & Not applicable \\
\hline
\end{tabular}

(with $70 \%$ residue) is evaluated by comparison with the control run.

\section{Results}

\subsection{Soil organic carbon}

Simulated SOC values from the control run range from $<2 \mathrm{~kg} \mathrm{C} \mathrm{m}^{-2}$ in the Southwest to $>20 \mathrm{~kg} \mathrm{C} \mathrm{m}^{-2}$ in the northern United States (Fig. 1). Average SOC values are lower in crop ecosystems than in natural vegetation systems because of biomass removal and other land management. The total stored SOC over all land surface types in the United States, as calculated by CLM-Crop, is $84 \mathrm{PgC}$, which falls within the range of previous estimates of 78-85 Pg C (Kern, 1994). CLM-Crop-simulated SOC for agricultural sites over the contiguous United States (CONUS) has a pattern similar to that of total SOC, with higher SOC in the northern part of the country and lower SOC in the southern regions.

The general spatial pattern of the model-calculated SOC over CONUS is evaluated by using available spatially gridded data sets of SOC. The data developed by the global soil carbon International Geosphere-Biosphere Program (IGBP; Global Soil Data Task Group, 2000) for CONUS are summarized in Fig. 1b. The SOC pattern and magnitude are similar to the model-calculated values (Fig. 1a). The differences between the model-calculated SOC and the IGBP data set are shown in Fig. 1c. In most regions, the percent difference between the data set and the model simulation is $<5 \%$. Areas with higher percent differences are in boreal regions, where CLM tends to underestimate soil carbon (Koven et al., 2013).

Figure 1 includes both managed and natural lands. To evaluate the model-simulated SOC over agricultural lands, we selected self-identified measurements of SOC from agricultural lands available from the International Soil Carbon Network (ISCN; 2014). This data set has over 4000 unique SOC measurements to $1 \mathrm{~m}$ depth from croplands over CONUS. Although CLM soil depth $(3.8 \mathrm{~m})$ is deeper than the observations $(1 \mathrm{~m})$, since nearly two-thirds of SOC is found within the top $1 \mathrm{~m}$ (Jobbagy and Jackson, 2000), the bulk of the soil carbon is still captured in the observations. Because the
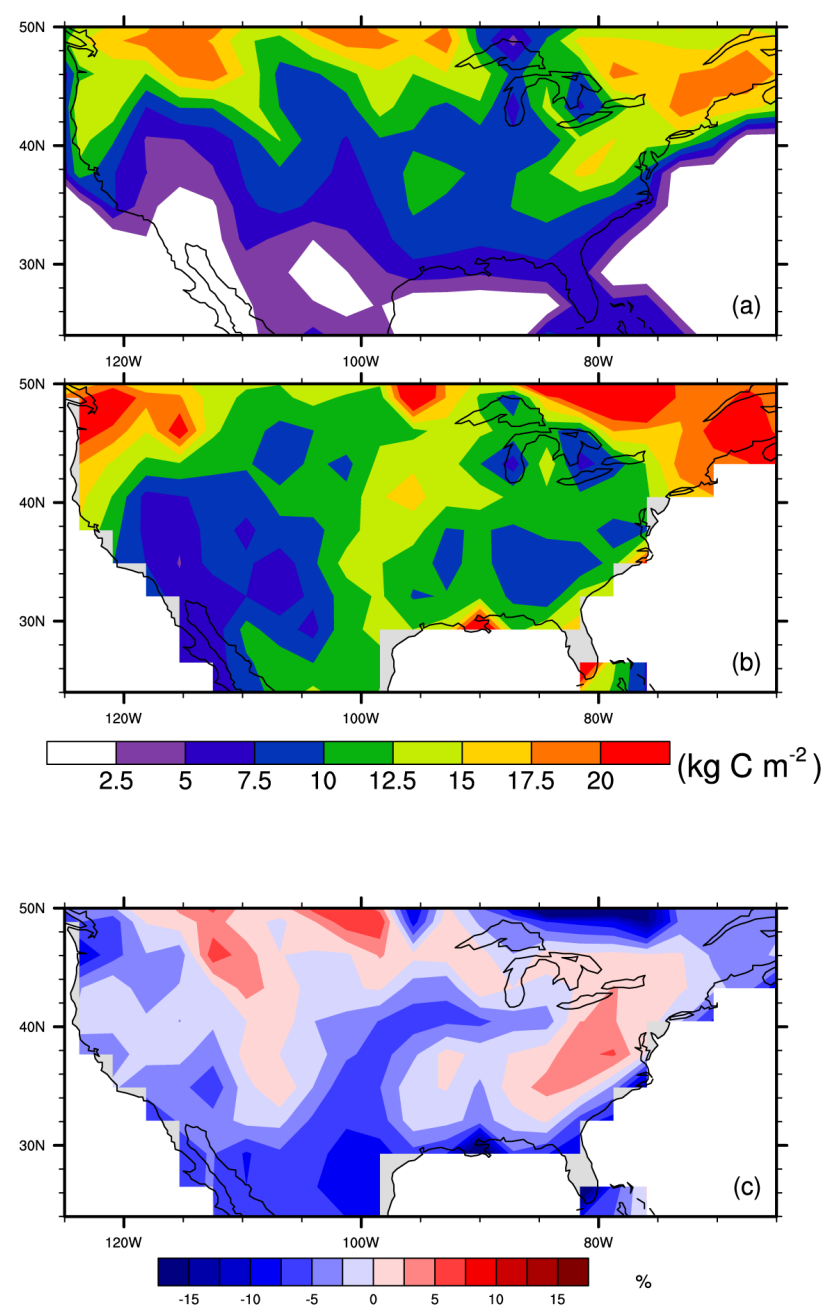

Figure 1. (a) Total SOC $\left(\mathrm{kg} \mathrm{C} \mathrm{m}^{-2}\right)$ simulated by CLM-Crop over the contiguous United States. (b) Total SOC from the IGBP over the same domain as in (a). (c) Percent difference between (a) and (b).

ISCN data were collected over a wide variety of soils, at different points in the crop cycle and different times since the change in land used, variability is large, and the number of outliers from the median of the sample is significant. The 
plot in Fig. 2 shows the range of values with significant occurrences in the upper quartile and above the 90th percentile of the distribution. We filtered out outliers with SOC measurements $>50 \mathrm{~kg} \mathrm{C} \mathrm{m}^{-2}$ in this figure only to improve readability of the graph, since only a small portion $(2.5 \%)$ of the measured values were higher than $50 \mathrm{~kg} \mathrm{C} \mathrm{m}^{-2}$, and SOC in agricultural lands is typically less than $50 \mathrm{~kg} \mathrm{C}$ (Kern et al., 1994; Mishra et al., 2010). The model results for the grid cells identified as cropland are included in Fig. 2. The model results have a smaller range than the ISCN data, as would be expected for SOC values extracted at the end of the simulation period and post-harvest. In addition, the SOC in the model is less variable because of the larger grid cells with uniform soil type. Nevertheless, the median SOC values simulated by CLM-Crop fall within range of the middle $50 \%$ of the ISCN measurements (Fig. 2), and thus the simulated values are comparable, on average, with the observations. In order to compensate for the mismatch of soil depth, we added an additional $36 \%$ of SOC to the observed stocks (to account for the $\sim$ one-third of carbon at soil depths of 2-3 m; Jobbagy and Jackson, 2000). The resulting increase in observed SOC (not shown) caused median CLM-Crop SOC stocks to fall outside the 50 percentile of the observations, but the top 75 percentile of CLM SOC still fall within the observed range.

In a further evaluation of the model's performance over agricultural lands, we completed a site-by-site comparison of modeled SOC to observed SOC. We applied a filter to separate soil over the modeling domain into three types (clay, sand, and silt), to examine the model behavior against the different textures. Figure 3 plots simulation results versus observations of SOC for values selected as described above. Each point indicates the mean observational SOC stock at the model grid scale with the standard deviation. The plot indicates that although the model does tend to underestimate soil carbon over croplands, CLM does reasonably well at catching a wide range of SOC values at agricultural sites for all soil textures. The model does not capture the individual site observations well $\left(\mathrm{RMSE}=13.1 \mathrm{~kg} \mathrm{C} \mathrm{m}^{-2}\right.$; $R^{2}=0.016$ ), due to the high spatial variability. CLM tends to simulate high SOC in sandy soils, low SOC for silt soils, and clay SOC in between; however, the soil texture is determined from the model data and therefore may not accurately represent the soil texture of the observations. This result is encouraging in view of difficulties in comparing CLMCrop-simulated SOC with observations at agricultural sites. First, the large grid size used in the model simulation cannot resolve the small-scale variability between farm-scale measurements, which are apparent from the large standard deviation in observations. Second, the model is run with static management for long time periods and cannot capture changes in management or land use over long temporal and large spatial resolutions while observations are taken over various time frames with vastly different land use histories. Finally, measurements are taken at $1 \mathrm{~m}$ depth, and CLMCrop estimates SOC for the total soil column $(>300 \mathrm{~cm})$.

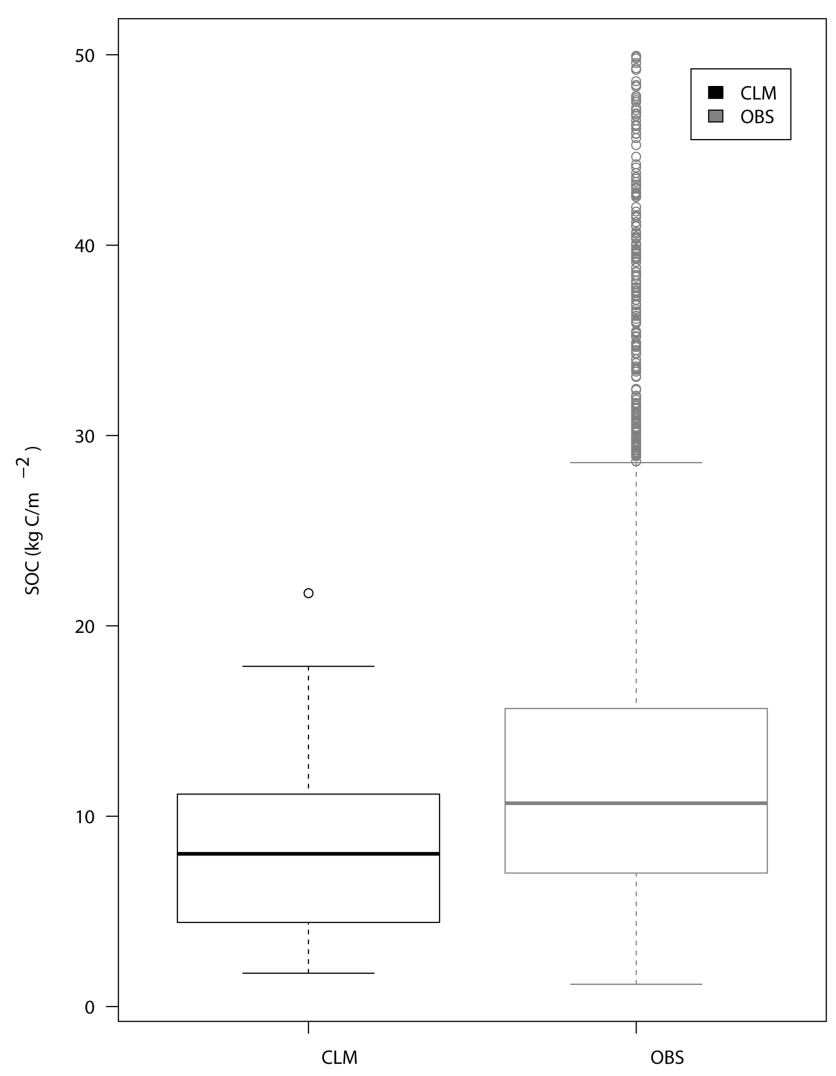

Figure 2. Box plot of the weighted average total SOC over croplands, as simulated in CLM-Crop and in observations from the ISCN. Observations reporting $>50 \mathrm{~kg} \mathrm{C} \mathrm{m}^{-2}$ were removed from the analysis.

When we attempt to adjust the observed SOC to include carbon at deeper soil layers (by adding $\sim$ one-third more carbon, as in Fig. 2), RMSE increases to $18.8 \mathrm{~kg} \mathrm{C} \mathrm{m}^{-2}$ although $R^{2}$ did not change. Despite these challenges, CLM can capture the range of SOC present at many agricultural sites and in many cases CLM SOC estimates fall within the standard deviation of the observations.

In order to explore the model performance further, we examined the effect of climate variability on SOC stocks. CLM SOC stocks decrease with increasing mean annual temperature and total annual precipitation (Fig. 4), which is also supported by observations. Higher temperatures and soil moisture generally result in higher belowground activity and therefore faster turnover of soil carbon (Wei et al., 2014). Natural vegetation follows the same temperature trends, but regions with higher annual precipitation indicate higher SOC stock. This is possibly the result of increased productivity when precipitation is high, however the variability in natural vegetation is quite large making conclusions difficult.

Finally, we also consider the ability of the model to capture temporal changes in SOC from land use conversion. Percent SOC loss since conversion from forest to agriculture, as summarized in Wei et al. (2014), is plotted in Fig. 5 over 


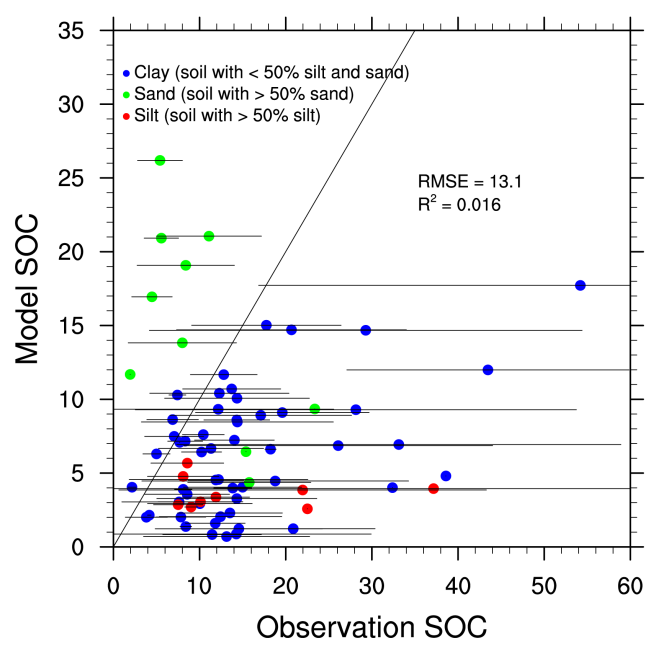

Figure 3. CLM-modeled SOC $\left(\mathrm{kg} \mathrm{C} \mathrm{m}^{-2}\right)$ versus ISCN observations for model-derived soil texture types clay, sand, and silt. Each point represents the mean observed SOC value in the grid cell; error bars show the standard deviation. The black line represents the $1: 1$ ratio.
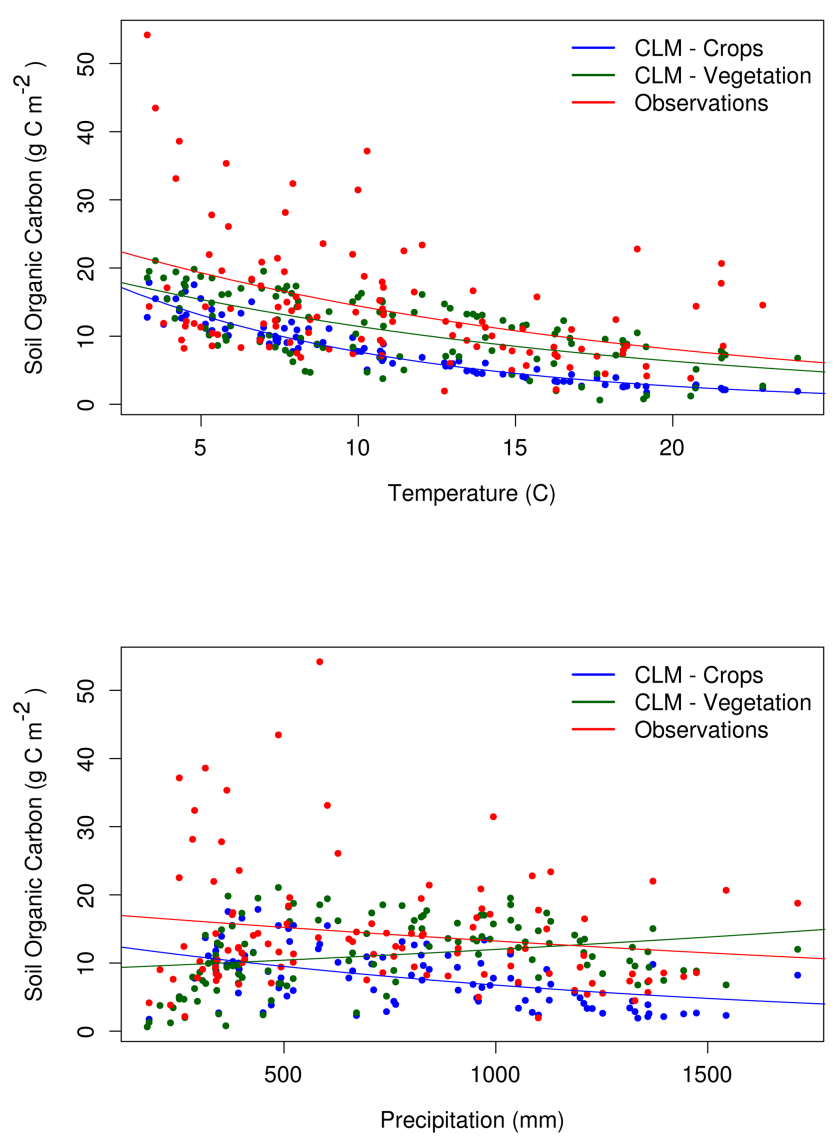

Figure 4. The effects of temperature (top) and precipitation (bottom) on SOC stock from CLM crops (blue), natural vegetation (green) and ISCN observations (red).

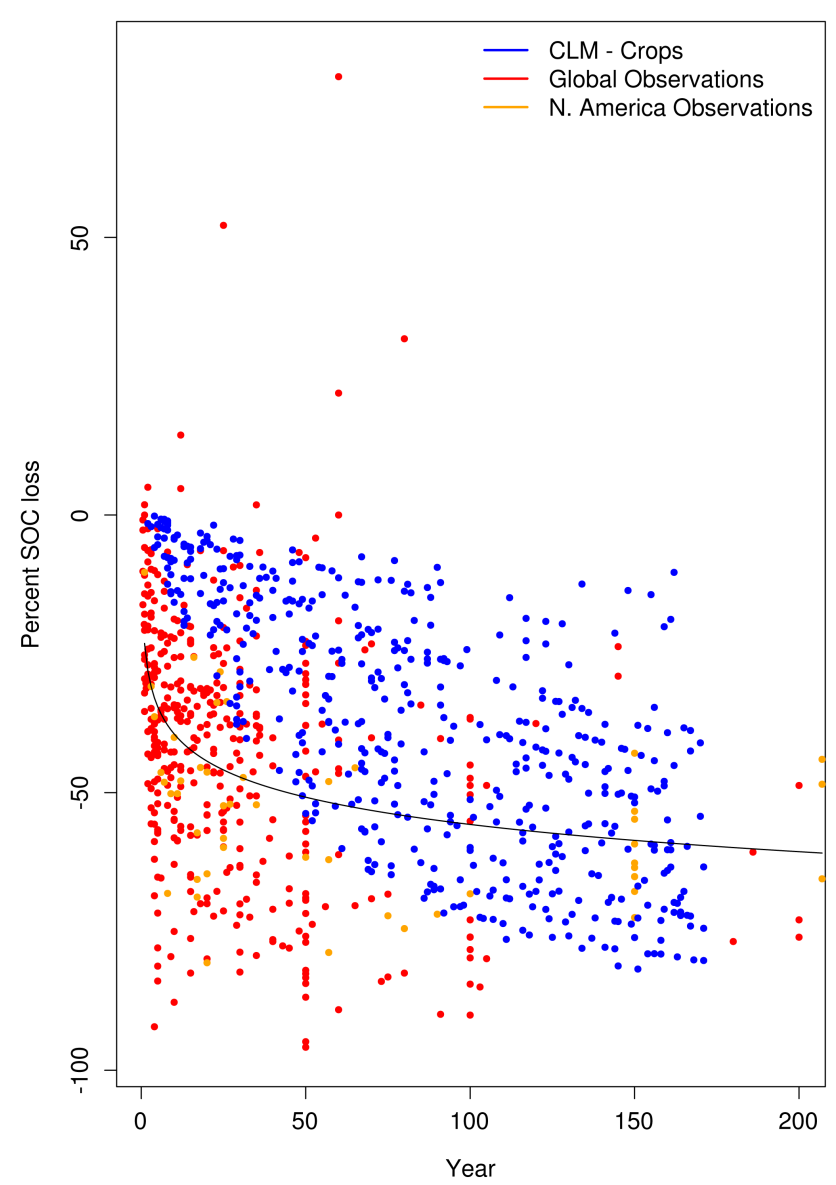

Figure 5. Percent decrease of SOC after conversion from natural vegetation to cropland. Percent decrease data from Wei et al. (2014) are in red (US points are orange) and CLM percent loss is blue.

temporal periods ranging from 1 to 207 years with a subset (500 points) of CLM SOC percent loss taken from random grids and time periods. Although CLM does not simulate the rapid loss of SOC that occurs in some field observations, by the end of the simulation, CLM does capture the range of SOC loss as seen in observations. Initial lower SOC stocks likely cause the initial modest decline in SOC simulated by the model, since SOC loss increases with increasing initial SOC concentration (Wei et al., 2014). This result highlights CLMs ability to capture changes in SOC over long time periods.

\subsection{CLM-Crop-simulated changes in soil carbon}

Most grid cells lost between 3 and $45 \%$ of total SOC, averaged across the grid cell. The amount of SOC lost was correlated with the size of the agricultural land base; higher agricultural land use resulted in larger SOC loss. Individual crop soil columns indicate high losses of SOC, up to a maximum of $75 \%$ of total SOC, although average soil loss is $33-51 \%$. Total loss also varied with crop type; maize and wheat lost 


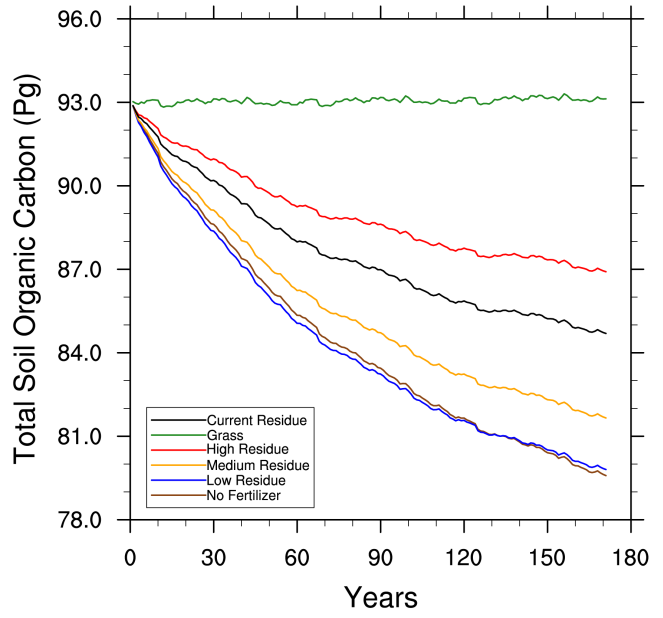

Figure 6. Simulated change in total US SOC $(\mathrm{Pg} \mathrm{C})$ due to agricultural land management for all scenarios.

about $10 \%$ less SOC than soybean. This is understandable, given the low residue of soybean crops, although this result varied with location. For example, total simulated SOC loss over maize and soybean soil columns at the Bondville site in Illinois was $48 \%$. At the Mead, Nebraska, site, losses of SOC for maize and soybean columns were approximately 44 and $52 \%$, respectively.

While these site-level SOC losses are comparable with observations (Lal, 2004), comparison with the SOC values in the control simulation might be exaggerated as a result of the subgrid hierarchy because the accumulated SOC estimated by the grass simulation was influenced by all vegetation types in the soil column, while the soil column in the control simulation only included one crop type. In addition, Ramankutty and Foley (1999) showed that most early croplands from the late 1800s were formed through deforestation and later prairie removal. This implies that our estimation might be exaggerated because grassland ecosystems can hold more carbon than forests (Schlesinger, 1997). Overall, a $10 \%$ loss in total SOC over the United States between the control run and the grass run accounts for a nationwide carbon loss of more than 8 Pg (Fig. 6).

Residue management can have the largest impact on soil carbon. Increasing the residue left on the field to $90 \%$ results in a $2.6 \%$ increase of SOC, but allowing a $10 \%$ residue amount (as a potential result of increased cellulosic biofuel demand) leaves an SOC decrease of over $5.7 \%$. The difference between these two scenarios is over $7 \mathrm{Pg} \mathrm{C}$, almost the same amount as the total carbon loss due to agricultural land use. Interestingly, we found no notable differences between crop responses. An even more modest decrease in the residue returned to the field (30-40\%) results in a $3.5 \%$ loss of SOC compared to the control simulation. Increasing the residue harvest will increase the amount of SOC loss (AndersonTeixeira et al., 2009; Blanco-Canqui and Lal, 2009b). Har-

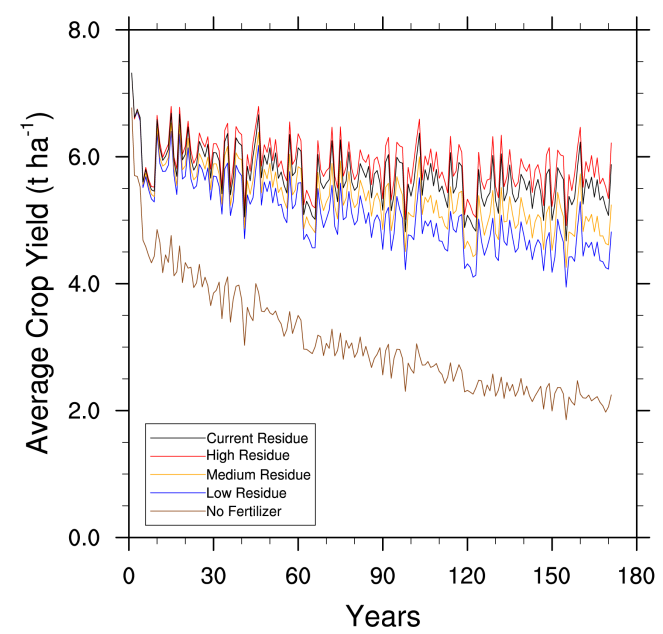

Figure 7. The effect of agricultural land management change on annual crop yield.

vesting residue results in the loss of not only soil carbon, but also soil fertility, indicated by declining yields (Fig. 7). This implies that increased residue harvest for cellulose might result in the expansion of croplands to counter yield declines.

Eliminating fertilizer use showed the biggest impact on yields and SOC, simulating over $6 \%$ loss (Fig. 6). Globally, decreases in yields of roughly $60-70 \%$ occurred for maize and wheat, but soybeans, relying less on fertilizer inputs, suffered a $22 \%$ decrease in yields. The different response between plant types was large: individual maize and wheat soil columns lost an average of $63 \%$ SOC, whereas soybean only lost $11 \%$. Despite low yields, leaving $70 \%$ residue allowed carbon inputs to maintain nearly the same SOC level as in the run with low residue return. This indicates a critical role for fertilization in soil carbon storage, without which an additional $5 \operatorname{Pg~C}$ might be lost due to cultivation. The observed result is not surprising, as fertilizer contributes to the total biomass accumulated during crop development, and increased biomass returned as residue will allow the soil to retain some of the nutrients taken up during crop growth, improving the soil fertility.

\section{Discussion}

CLM-Crop has proven to be a valuable tool for evaluating changes in soil carbon under various management practices. Our results indicate that the SOC for agricultural sites will be reduced through any management practice while disturbance continues, with the total amount lost depending on the management practice. Model-estimated US losses of SOC due to current cultivation practices are around $10 \%$, with a potential for greater loss as the amount of harvested residue increases.

The amount of biomass residue left on the field after grain harvest has the most significant effect on SOC. Cellulosic biofuels rely on harvesting the stems and leaves of crops, re- 


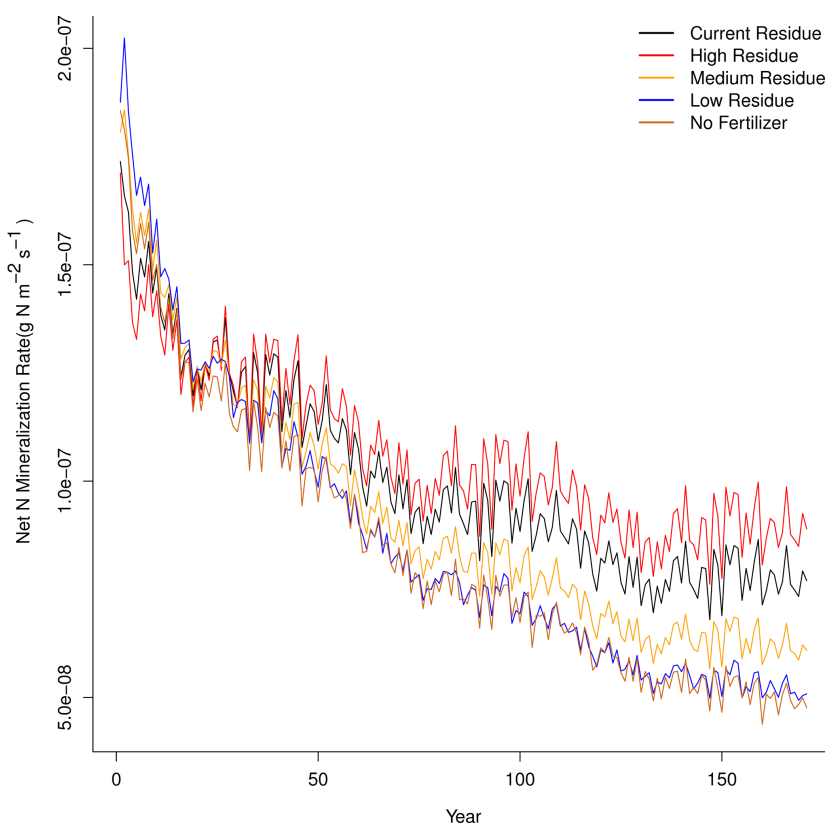

Figure 8. The effect of agricultural land management change on crop annual average nitrogen uptake.

sulting in an additional $5 \%$ loss of carbon within the soil system. Currently, model subgrids growing a single crop type on an independent soil column typically lose $33-51 \%$ of SOC, and that loss increases to nearly $90 \%$ when residue is harvested. Over long timescales, this effect can degrade the sustainability of the soil for crop growth and can negatively affect yield. For example, plant nitrogen uptake (Fig. 8) decreases linearly with increasing residue harvest. The high residue returns uptake $7.4 \%$ more $\mathrm{N}$ than the current residue runs, whereas medium and low residue returns have 6.6 and $15.6 \%$ lower $\mathrm{N}$ uptake, respectively. When fertilizer is not included, the resulting $\mathrm{N}$ uptake is $57 \%$ lower. This impact is transferred to yields (Fig. 7), resulting in 9 and $17 \%$ lower yields for the medium and low residue returns, respectively. Thus, the effects of residue management on SOC are very important, and increasing the amount of residue used for cellulosic ethanol production could have a significant impact on soil carbon storage and ultimately plant productivity. Leaving plant residue from crop production in the soil decreases the amount of carbon lost to the atmosphere. However, meeting cellulosic biofuel demand through cultivation of managed grasses such as switchgrass and miscanthus has been shown to increase soil carbon storage over time (AndersonTeixeira et al., 2009), most likely because nutrient demands and management practices are different for these types of biofuel crops.

Disagreement between studies about the possible effect of fertilizer on SOC leaves this management practice open for further research. Our findings suggest that fertilizer use might improve yield and increase the amount of carbon re- turned to the soil in crop residue; however, increased residue removal for biofuels could reduce this effect. As fertilizers improve and are applied to maximize plant uptake while minimizing loss to leaching and denitrification, fertilizer might provide an important tool for farmers to mitigate the soil carbon loss due to increasing residue harvest for biofuel use. However, care must be taken to ensure that fertilizer inputs do not exceed plant uptake, which could result in increased nitrogen leached into the groundwater and increased greenhouse gas emission of $\mathrm{N}_{2} \mathrm{O}$ via nitrification and denitrification pathways. The effect of increased decomposition when fertilizer is used also needs to be explored.

Expanding the model to incorporate other management practices (rotation, tillage, irrigation, etc.) is an important activity for future model development. Erosion, for example, is expected to increase as a result of crop residue harvest (Lal and Pimentel, 2007). This secondary effect of residue harvest can have multiple consequences. First, soil fertility will decline with the loss or transport of soil organic matter. Second, erosion processes result in the breakdown of soil aggregates promoting oxidation of SOC. Both effects will reduce the nutrient and water-holding capacities of the soil (Lal and Pimentel 2008). Finally, the loss of nutrients will result in a decline of crop productivity, further enhancing SOC loss. As such, our results should be considered as lower bound estimates of SOC loss from residue harvest. Including these effects and expanding agricultural models to a global scale should be a priority for future model development. Given the challenges of comparing with observations, focusing on model developments that capture cropland SOC dynamics is equally as important as developing data sets that can be used for climate model validation, especially considering the increasing complexity of Earth system models that include cropland representation. Although the crop representation in CLM-Crop is flexible enough for expansion to a global scale, rigorous testing is needed to ensure that crop behavior is consistent with regional observations.

There are some limitations to our modeling approach that lead to uncertainties in the model prediction of SOC. For example, changes in land use and land cover are not included in CLM. Historical changes in land use indicate a steady increase in cultivated land which peaked in the 1940s and declined thereafter (Waisanen and Bliss, 2002). Using a modern land use cover over the historical period may result in an overprediction of SOC loss because the model will overestimate the agricultural land base in some (early) years and the model will not capture increases in SOC when agricultural land is abandoned. This also limits the influence of beneficial agricultural practices such as crop rotation and fallowing. Historical changes in land management are also not represented in the model, such as changes in residue harvest over time or organic matter additions. For example, Lal et al. (1999) suggested that early cultivation removed residue following harvest until after 1940 when residue was returned to the field. The high spatial variability and difficulty of find- 
ing these types of historical data is a major challenge for trying to add these features to CLM.

Finally, further research is needed for the full evaluation of the importance of agro-ecosystem impacts on soil carbon. We have shown here that SOC loss can vary greatly, depending on management practices. Practices such as residue management can have significant impact on SOC retained in agricultural soils, with higher residue removal from soil leading to higher SOC losses. The use of fertilizer can compensate for some of the loss, but the benefit is limited. Further modeling studies are important for simulating these competing effects on carbon storage. Our study suggests that considerable care is needed in designing appropriate management practices to realize the full carbon mitigation benefits of using biofuels from cellulosic ethanol.

Acknowledgements. This work was supported by the US Department of Energy (DOE), Office of Science, under contract DE-AC02-06CH11357. Numerical simulations were performed with resources provided by the National Energy Research Scientific Computing Center, supported by the Office of Science, under DOE contract DE-AC02-05CH11231.

Edited by: A. Ito

\section{References}

Ananyeva, K., Wang, W., Smucker, A. J. M., Rivers, M. L., and Kravchenko, A. N.: Can intra-aggregate pore structures affect the aggregate's effectiveness in protecting carbon?, Soil Biol. Biogeochem., 57, 868-875, 2013.

Anderson-Teixiera, K., Davis, S. C., Masters, M. D., and Delucia, E. H.: Changes in soil organic carbon under biofuel crops, Glob. Change Biol., 1, 75-96, 2009.

Blanco-Canqui, H. and Lal, R.: Crop residue removal impacts on soil productivity and environmental quality, Plant Sci., 28, 139163, 2009a.

Blanco-Canqui, H. and Lal, R.: Corn stover removal for expanded uses reduces soil fertility and structural stability, Soil Sci. Soc. Am. J., 73, 418-426, 2009b.

Bonan, G. B., Levis, S., Kergoat, L., and Oleson, K. W.: Landscapes as patches of plant functional types: An integrating concept for climate and ecosystem models, Global Biogeochem. Cy., 16, 1021, doi:10.1029/2000GB001360, 2002.

Buyanovsky, G. A. and Wagner, G. H.: Changing role of cultivated land in the global carbon cycle, Biol. Fertil. Soils, 27, 242-245, 1998.

Conant, R. T., Paustian, K., and Elliott, E. T.: Grassland management and conservation into grassland: Effects on soil carbon, Eccol. Appl., 11, 343-355, 2001.

Dou, F. and Hons, F. M.: Tillage and nitrogen effects on soil organic matter fractions in wheat-based systems, Soil Sci. Soc. Am. J., 70, 1896-1905, 2006.

Drewniak, B., Song, J., Prell, J., Kotamarthi, V. R., and Jacob, R.: Modeling agriculture in the Community Land Model, Geosci. Model Dev., 6, 495-515, doi:10.5194/gmd-6-495-2013, 2013.
EISA, Energy Independence and Security Act of 2007, H.R. 6, 110th Cong., available at: http://frwebgate.access.gpo. gov/cgi-bin/getdoc.cgi?dbname=110_cong_bills\&docid=f: h6enr.txt.pdf (last access: 21 July 2013), 2007.

Fargione, J., Hill, J. Tilman, D. Polasky, S., and Hawthorne, P.: Land clearing and the biofuel carbon debt, Science, 319, 1235-1238, 2008.

Gibbs, H. K., Johnston, M., Foley, J. A., Holloway, T., Monfreda, C., Ramankutty, N., and Zaks, D.: Carbon payback times for crop-based biofuel expansion in the tropics: The effects of changing yield and technology, Environ. Res. Lett., 3, 034001, doi:10.1088/1748-9326/3/3/034001, 2008.

Global Soil Data Task Group. Global Gridded Surfaces of Selected Soil Characteristics (IGBP-DIS), International GeosphereBiosphere Programme - Data and Information System, available at: http://www.daac.ornl.gov (last access: 15 April 2014), doi:10.3334/ORNLDAAC/569, 2000.

Halvorson, A. D., Reule, C. A., and Follett, R. F.: Nitrogen fertilization effects on soil carbon and nitrogen in a dryland cropping system, Soil Sci. Soc. Am. J., 63, 912-917, 1999.

Hooker, B. A., Morris, T. F., Peters, R., and Cardon, Z. G.: Longterm effects of tillage and corn stalk return on soil carbon dynamics, Soil Sci. Soc. Am. J., 69, 188-196, 2005.

Houghton, R. A., Hackler, J. L., and Lawrence, K. T.: The U.S. carbon budget: Contributions from land-use change, Science, 285, 574-578, 1999.

Huggins, D. R., Allmaras, R. R., Clapp, C. E., Lamb, J. A., and Randall, G. W.: Corn-soybean sequence and tillage effects on soil carbon dynamics and storage, Soil Sci. Soc. Am. J., 71, 145-154, 2007.

Hughes, J. K., Lloyd, A. J., Huntingford, C., Finch, J. W., and Harding, R. J.: The impact of extensive planting of Miscanthus as an energy crop on future $\mathrm{CO}_{2}$ atmospheric concentrations, $\mathrm{GCB}$ Bioenergy, 2, 79-88, 2010.

International Soil Carbon Network, International soil carbon database, available at: https://iscn.fluxdata.org/Pages/default. aspx (last access: 24 March 2015), 2014.

IPCC: Climate Change 2013: The Physical Science Basis. Contribution of Working Group I to the Fifth Assessment Report of the Intergovernmental Panel on Climate Change, edited by: Stocker, T. F., Qin, D., Plattner, G.-K., Tignor, M., Allen, S. K., Boschung, J., Nauels, A., Xia, Y., Bex V., and Midgley, P. M., Cambridge University Press, Cambridge, United Kingdom and New York, NY, USA, 2013.

Jobbagy, E. G. and Jackson, R. B.: The vertical distribution of soil organic carbon and its relation to climate and vegetation, Ecol. Appl., 10, 423-436, 2000.

Johnson, J. M. F., Reicosky, D. C., Allmaras, R. R., Sauer, T. J., Venterea, R. T., and Dell, C. J.: Greenhouse gas contributions and mitigation potential of agriculture in the central USA, Soil and Tillage Research, 83, 73-94, 2005.

Jung, J. Y. and Lal, R.: Impacts of nitrogen fertilization on biomass production of switchgrass (Panicum virgatum $\mathrm{L}$.) and changes in soil organic carbon in Ohio, Geoderma, 166, 145-152, 2011.

Kalnay, E., M. Kanamitsu, R. Kistler, W. Collins, D. Deaven, L. Gandin, M. Iredell, S. Saha, G. White, J. Woollen, Y. Zhu, M. Chelliah, W. Ebisuzaki, W. Higgins, J. Janowiak, K., Mo, C., Ropelewski, C., Wang, J., Leetmaa, A., Reynolds, R., Jenne, R., and 
Joseph, D.: The NCEP/NCAR 40-year reanalysis project, B. Am. Meteorol. Soc., 77, 437-470, 1996.

Karlen, D. L., Lal, R., Follett, R. F., Kimble, J. M., Miranowski, J. M., Cambardella, C. A., Manale, A., Anex, R. P., and Rice, C. W.: Crop residues: the rest of the story, Environ. Sci. Technol., 43, 8011-8015, 2009.

Karlen, D. L., Varvel, G. E., Johnson, J. M. F., Baker, J. M., Osborne, S. L., Novak, J. M., Adler, P. R., Roth, G. W., and Birrell, S. J.: Monitoring soil quality to assess the sustainability of harvesting corn stover, Agron. J., 103, 288-295, 2011.

Kern, J. S.: Spatial patterns of soil organic carbon in the contiguous United States, Soil Sci. Soc. Am. J., 58, 439-455, 1994.

Khan, S. A., Mulvaney, R. L., Ellsworth, T. R., and Boast, C. W.: The myth of nitrogen fertilization for soil carbon sequestration, J. Environ. Qual, 36, 1821-1832, 2007.

Kim, H., Kim, S., and Dale, B. E.: Biofuels, land use change, and greenhouse gas emissions: Some unexplored variables, Environ. Sci. Technol., 43, 961-967, 2009.

Koven, C. D., Riley, W. J., Subin, Z. M., Tang, J. Y., Torn, M. S., Collins, W. D., Bonan, G. B., Lawrence, D. M., and Swenson, S. C.: The effect of vertically resolved soil biogeochemistry and alternate soil $\mathrm{C}$ and $\mathrm{N}$ models on C dynamics of CLM4, Biogeosciences, 10, 7109-7131, doi:10.5194/bg-10-7109-2013, 2013.

Kravchenko, A. N. and Robertson, G. P.: Whole-profile soil carbon stocks: The danger of assuming too much from analysis of too little, Soil Sci. Soc. Am. J., 75, 235-240, 2011.

Kucharik, C. J. and Brye, K. R.: Integrated BIosphere Simulator (IBIS) yield and nitrate loss predictions for Wisconsin maize receiving varied amounts of nitrogen fertilizer, J. Environ. Qual., 32, 247-268, 2003.

Lal, R.: Soil carbon dynamics in cropland and rangeland, Environ. Pollut., 116, 353-352, 2002.

Lal, R.: Soil carbon sequestration impacts on global climate change and food security, Science, 304, 1623-1627, 2004.

Lal, R.: Soil quality impacts of residue removal for bioethanol production, Soil and Tillage Research, 102, 233-241, 2009.

Lal, R. and Bruce, J. P.: The potential of world cropland soils to sequester $\mathrm{C}$ and mitigate the greenhouse effect, Environ. Sci. Policy, 2, 177-185, 1999.

Lal, R. and Pimentel, D.: Biofuels from crop residues, Soil and Tillage Research, 93, 237-238, 2007.

Lal, R. and Pimentel, D.: Soil Erosion: A carbon sink or source?, Science, 319, 1040-1042, 2008.

Lal, R., Kimble, J. M., Follett, R. F., and Cole, C. V.: The potential of U.S cropland to sequester carbon and mitigate the greenhouse effect, Ann Arbor Press, Chelsea, MI, 1999.

Leff, B., Ramankutty, N., and Foley, J. A.: Geographic distribution of major crops across the world, Global Biogeochem. Cy., 18, GB1009, doi:10.1029/2003GB002108, 2004.

Lemke, R. L., VandenBygaart, A. J., Campbell, C. A., Lafond, G. P., and Grant, B.: Crop residue removal and fertilizer N: Effects on soil organic carbon in a long-term crop rotation experiment on a Udic Boroll, Agr. Ecosyst. Environ., 135, 42-51, 2010.

Mellio, J. M., Reilly, J. M., Kicklighter, D. W., Gurgel, A. C., Cronin, T. W., Paltsev, S., Felzer, B. S., Wang, X., Sokolov, A. P., and Schlosser, C. A.: Indirect emissions from biofuels: How important?, Science, 326, 1397-1399, 2009.
Mishra, U., Lal, R., Liu, D., and Van Meirvenne, M.: Predicting the spatial variation of soil organic carbon pool at a regional scale, Soil Sci. Soc. Am. J., 74, 906-914, 2010.

Mishra, U., Torn, M. S., and Fingerman, K.: Miscanthus biomass productivity within U.S. croplands and its potential impact on soil organic carbon, Glob. Change Biol., 5, 391-399, doi:10.1111/j.1757-1707.2012.01201.x, 2013.

McKone, T. E., Nazaroff, W. W., Berck P., Auffhammer, M., Lipman, T., Torn, M. S., Masanet, E., Lobscheid, A., Santero, N., Mishra, U., Barrett, A., Bomberg, M., Fingerman, K., Scown, C., Stogen, B., and Horvath, A.: Grand Challenges for life-cycle assessment of biofuels, Environ. Sci. Technol., 45, 1751-1756, 2011.

Neitsch, S. L., Arnold, J. G., Kiniry, J. R., and Williams J. R.: Soil and Water Assessment Tool, Theoretical Documentation: Version 2005, USDA Agricultural Research Service and Texas A\&M Blackland Research Center, Temple, TX, 2005.

New, M., Hulme, M., and Jones, P. D.: Representing twentiethcentury space-time climate variability. Part I: Development of a 1961-90 mean monthly terrestrial climatology, J. Climate, 12, 829-856, 1999.

Pineiro, G., Jobbagy, E. G., Baker, J., Murray, B. C., and Jackson, R. B.: Set-asides can be better climate investment than corn ethanol, Eco. Appl., 19, 277-282, 2009.

Ramankutty, N. and Foley, J. A.: Estimating historical changes in global land cover: Croplands from 1700 to 1992, Global Biogeochem. Сy., 13, 997-1027, 1999.

Russell, A. E., Cambardella, C. A., Laird, D. A., Jaynes, D. B., and Meek, D. W.: Nitrogen fertilizer effects on soil carbon balances in midwestern U.S. agricultural systems, Ecol. Appl., 19, 11021113, 2009.

Sacks, W. J., Deryng, D., Foley, J. A., and Ramankutty, N.: Crop planting dates: An analysis of global patterns, Global Ecol. Biogeogr., doi:10.1111/j.1466-8238.2010.00551.x, 2010.

Schlesinger, W. H.: Biogeochemistry: An Analysis of Global Change, Academic Press, San Diego, CA, 1997.

Searchinger, T., Heimlick, R., Houghton, R. A., Dong, F., Elobeid, A., Fabiosa, J., Tokgoz, S., Hayes, D., and Yu, T.-H.: Use of U.S. croplands for biofuels increases greenhouse gases through emissions from land use change, Science, 319, 1238-1240, 2008.

Senthilkumar, S., Basso, B., Kravchenko, A. N., and Robertson, G. P.: Contemporary evidence of soil carbon loss in the U.S. corn belt, Soil Sci. Soc. Am. J., 73, 2078-2086, 2009a.

Senthilkumar, S., Kravchenko, A. N., and Robertson, G. P.: Topography influences management system effects on total soil carbon and nitrogen, Soil Sci. Soc. Am. J., 73, 2059-2067, 2009 b.

Smith, W. N., Grant, B. B., Campbell, C. A., McConkey, B. G., Desjardins, R. L., Krobel, R., and Malhi, S. S.: Crop residue removal effects on soil carbon: Measured and inter-model comparisons, Agr. Ecosyst. Environ., 161, 27-38, 2012.

Syswerda, S. P., Corbin, A. T., Mokma, D. L., Kravchenko, A. N., and Robertson, G. P.: Agricultural management and soil carbon storage in surface vs. deep layers, Soil Sci. Soc. Am. J., 75, 92101, doi:10.2136/sssaj2009.0414, 2011.

Tan, Z., Liu, S., Bliss, N., and Tieszen, L. L.: Current and potential sustainable corn stover feedstock for biofuel production in the United States, Biomass Bioenerg., 47, 372-386, 2012. 
Thornton, P. E. and Rosenbloom, N.: Ecosystem model spin-up: Estimating steady state conditions in a coupled terrestrial carbon and nitrogen cycle model, Ecol. Model., 189, 25-48, 2005.

Thorburn, P. J., Meier, E. A., Collins, K., and Robertson, F. A.: Changes in soil carbon sequestration, fractionation and soil fertility in response to sugarcane residue retention are site-specific, Soil and Tillage Research, 120, 99-111, 2012.

US Environmental Protection Agency, Regulation of Fuels and Fuel Additives: Changes to Renewable Fuel Standard Program; Final Rule, Federal Register, 5, 14670-14904, 2010.

van Groenigen, K. J., Hastings, A., Forristal, D., Roth, B., Jones, M., and Smith, P.: Soil C storage as affected by tillage and straw management: An assessment using field measurements and model predictions, Agr. Ecosyst. Environ., 140, 218-225, 2011.

Van Pelt, R. S., Baddock, M. C., Zobeck, T. M., Schlegel, A. J., Vigil, M. F., and Acosta-Martinez, V.: Field wind tunnel testing of two silt loam soils on the North American central high plains, Aeolian Research, 10, 53-59, 2013.
Waisanen, P. J. and Bliss, N. B.: Changes in population and agricultural land in conterminous United States counties, 1790-1997, Global Biogeochem. Cy., 16, 1137, doi:10.1029/2001GB001843, 2002.

Wei, X., Shao, M., Gale, W., and Li, L.: Global pattern of soil carbon losses due to the conversion of forests to agricultural land, Scientific Reports, 4, 4062, doi:10.1038/srep04062, 2014.

West, T. O. and Post, W. M.: Soil organic carbon sequestration rates by tillage and crop rotation: A global data analysis, Soil Sci. Soc. Am. J., 66, 1930-1946, 2002.

Wilhelm, W., Johnson, J. M. F., Hatfield, J. L., Voorhees, W. B., and Linden, D. R.: Crop and soil productivity response to corn residue removal: A literature review, Agron. J., 96, 1-17, 2004.

Wilts, A. R., Reicosky, D. C., Allmaras, R. R., and Clapp, C. E.: Long-term corn residue effects: Harvest alternatives, soil carbon turnover, and root-derived carbon, Soil Sci. Soc. Am. J., 68, 1342-1351, 2004. 